\title{
Corrigendum: Leukocyte integrin Mac-1 regulates thrombosis via interaction with platelet GPIb $\alpha$
}

Yunmei Wang, Huiyun Gao, Can Shi, Paul W. Erhardt, Alexander Pavlovsky, Dmitry A. Soloviev, Kamila Bledzka, Valentin Ustinov, Liang Zhu, Jun Qin, Adam D. Munday, Jose Lopez, Edward Plow \& Daniel I. Simon

Nature Communications 8:15559 doi: 10.1038/ncomms15559 (2017); Published 30 May 2017; Updated 4 Jul 2017

The original version of this Article contained an error in the email address of the corresponding author Daniel I. Simon. The correct email is Daniel.Simon@UHHospitals.org. The error has been corrected in the HTML and PDF versions of the article.

\footnotetext{
(c) (†)

Open Access This article is licensed under a Creative Commons Attribution 4.0 International License, which permits use, sharing, adaptation, distribution and reproduction in any medium or format, as long as you give appropriate credit to the original author(s) and the source, provide a link to the Creative Commons license, and indicate if changes were made. The images or other third party material in this article are included in the article's Creative Commons license, unless indicated otherwise in a credit line to the material. If material is not included in the article's Creative Commons license and your intended use is not permitted by statutory regulation or exceeds the permitted use, you will need to obtain permission directly from the copyright holder. To view a copy of this license, visit http://creativecommons.org/licenses/by/4.0/
}

(C) The Author(s) 2017 